\title{
Social competence of physicians and medical students - a preliminary report
}

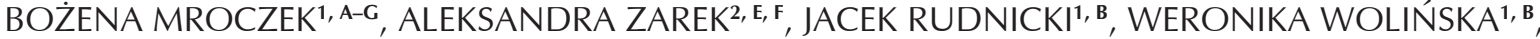

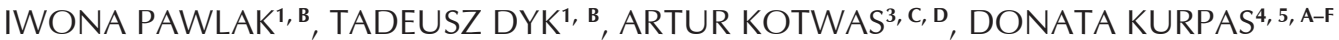 \\ ${ }^{1}$ Department of Human Sciences in Medicine, Pomeranian Medical University in Szczecin \\ ${ }^{2}$ Department of Humanistic Sciences in Medicine, Medical University of Wroclaw \\ ${ }^{3}$ Chair and Department of Public Health, Pomeranian Medical University in Szczecin \\ ${ }^{4}$ Chair and Department of Family Medicine, Medical University of Wroclaw \\ ${ }^{5}$ Opole Medical School
}

A - Study Design, B - Data Collection, C - Statistical Analysis, D - Data Interpretation, E - Manuscript Preparation, $\mathbf{F}$ - Literature Search, $\mathbf{G}$ - Funds Collection

Summary Background. Efficient functioning at work and in the environment depends on social and emotional competence, understood as complex skills that determine the effectiveness of behaviors in various professional and social situations. Objectives. The aim of this study was to determine the social competence of physicians and medical students with regard to the sociodemographic contributors which shape social competence.

Material and methods. The study was conducted in 2015 and 2016 and it involved 90 physicians, including 25 GPs (27.8\%) and 53 medical students of PMU in Szczecin. The median age of the physicians and the students was 32 and 25, respectively. The Social Competencies Questionnaire (SCQ) by Anna Matczak and a self-developed survey questionnaire were employed. Results. The ability of physicians to achieve medium and high levels of social competence increases by $8.5 \%$ with every year of seniority. Membership in scientific societies increases the odds of a high level of social competence fivefold in the ES scale and fourfold in the A scale. Physicians involved in the education of medical students were less likely to obtain medium and high scores (5 stens) in the A scale. An increase in seniority in the last workplace is accompanied by a 0.93 times lower probability of obtaining a high competence score in the A scale. Similarly, third cycle degree studies increase the odds of achieving high competence level by 7.48 times in the A scale.

Conclusions. Low levels of competence can be expected from physicians with less seniority, not belonging to scientific societies, not involved in students' education, working in only one place, and not participating in third cycle degree studies. This group should be provided with social competence training.

Key words: physician, general practitioner, medical student, social competence, Social Competencies Questionnaire (SCQ).

Fam Med Prim Care Rev 2016; 18(3): 308-312

\section{Background}

The term "competence" was introduced in 1959 by Robert White for a complete description of human behavior. White understood competence as the ability of individuals to effectively interact with the environment, acquired in the process of learning, and not only in the course of adolescence [1]. In the case of social competence, the indicator is the effectiveness of human functioning in social situations, defined as the effectiveness of an individual in achieving his/her own goals, the ability to build interpersonal relationships, in the absence of excessive psychological and psychophysiological costs, and the adequacy of behavior in relation to social standards [2].

Matczak defined social competence as complex skills allowing the individual to effectively deal with certain situations, revealed by the specific behaviors of an individual, in situations involving other people [3]. Individual differences in this area result directly from the effectiveness and intensity of the social training to which individuals are subjected during their life, associated with social and professional relations [2, 3]. Intensity of social training is influenced by temperamental and personality traits which motivate the individual to get involved in social situations $[2,3]$. On one hand, these characteristics include traits of an individual shaping his/her need for stimulation (resistance to agitation, activity, extraversion, neuroticism, emotional reactivity) [2-4], which on the other hand are indicators of active style of functioning - conscientiousness, sense of internal control in relation to success, task-oriented style of fighting stress [3].

The level of social competence is associated with professional interests and preferences, as well as professional functioning. People having higher social competence more often reveal interests in leadership and organization, as well as in care and service, and therefore they declare a desire to practice professions requiring intensive contact with other people $[3,5]$. The studies demonstrate that social competencies depend on mental wellbeing, overall life satisfaction, quality of interpersonal relationships, willingness to provide support to others, but also benefiting from social support, effective strategies for fighting stress, adaptation, and satisfactory social functioning [6-8].

The social competence of representatives of medical professions is a subject of increasing interest for researchers, for whom contact with people in need of help is a working tool requiring special skills in the field of making contacts, acquiring and sharing information, and influencing others [9-12]. The researchers believe that the social competencies of physicians, especially verbal and nonverbal communication, are associated with the degree of adherence of patients 
to the physician's recommendations [11, 13-14], which is considered by WHO to be one of the major health problems that prevent the achievement of the benefits of therapy based on current medical knowledge [15].

\section{Objectives}

The study was conducted to determine the social competence of physicians and medical students. Furthermore, the study was aimed at determining socio-demographic indicators (age, sex, marital status, education) and variables important in the process of social training (seniority in the profession, workplace, membership in scientific societies and social organizations, involvement in the education of students and co-workers) shaping the level of social competence.

\section{Material and methods}

The study obtained a positive opinion of the Bioethics Committee of the Pomeranian Medical University - PMU (KB-0012/92/12/2014). The study was conducted in late 2015 and early 2016, and it involved 90 physicians, including $27.8 \%$ (25) of general practitioners and 53 medical students at the Faculty of Medicine of PMU in Szczecin. Participation in the study was voluntary and anonymous. Age of physicians: $\mathrm{Me}=32$ (min.-max.: 24-66 years old), of students: $M e=25$ (min.-max.: 23-29 years old) (Tab. 1). The physicians were employed in healthcare entities in Szczecin
(77.78\%; 70) and Wrocław $(22.22 \% ; 20)$. In the group of physicians $31.11 \%$ (28) currently study for the third cycle degree.

The Social Competencies Questionnaire (SCQ) by Anna Matczak was employed [3]. It is a self-report tool with items which express different activities or tasks. It is required to assess the effectiveness with which individual activities and tasks are performed using a four point scale: definitely well, not badly, rather badly, definitely badly. The total number of items is 90, including 60 diagnostic items concerning social competence, while 30 are non-diagnostic items. The sum of diagnostic items constitutes a total (combined) result, consisting of three factorial scales, describing qualitatively different social competencies conditioning the effectiveness of behaviors in the following situations:

- intimate: scale $\boldsymbol{I}$ - close interpersonal contact, 15 items (15-60 points);

- $\quad$ social exposure: $\boldsymbol{E S}$ scale, 18 items (18-72 points);

- requiring assertiveness: scale $\boldsymbol{A}, 17$ items (17-68 points) $[3,11]$.

The results obtained in points were compared to sten scores. Sten scores from 1 to 3 indicate low results, 4-7 - average results, while from 8 to 10 - high results [3].

\section{Statistical analysis}

The total (combined) result of social competence did not have a normal distribution, as determined by the Shapiro-Wilk test. Age, which was one of the variables in the conducted study, also did not have a normal distribution. In order to investigate the relationship of adopted factors

\begin{tabular}{|c|c|c|c|c|}
\hline \multirow[t]{2}{*}{ Variable } & Total $n(\%)$ & Physicians $n$ (\%) & Students $n(\%)$ & \multirow{2}{*}{$\begin{array}{l}\mathrm{Z} / \mathrm{rho} / \mathrm{chi}^{2} \\
\mathrm{p}\end{array}$} \\
\hline & $143(100.0)$ & $90(62.5)$ & $53(37.5)$ & \\
\hline $\begin{array}{l}\text { Sex } \\
\text { women } \\
\text { men }\end{array}$ & $\begin{array}{l}01(70.6) \\
42(29.4)\end{array}$ & $\begin{array}{l}60(66.66) \\
30(33.33)\end{array}$ & $\begin{array}{l}41(75.92) \\
13(24.07)\end{array}$ & $\begin{array}{l}Z=-1.774 \\
p=0.076\end{array}$ \\
\hline $\begin{array}{l}\text { Age Me } \\
\text { min.-max. }\end{array}$ & $\begin{array}{l}28.00 \\
23-66\end{array}$ & $\begin{array}{l}32.00 \\
24-66 \text { years old }\end{array}$ & $\begin{array}{l}25.00 \\
23-29 \text { years old }\end{array}$ & $\begin{aligned} Z & =-9.134 \\
p & =0.0001\end{aligned}$ \\
\hline $\begin{array}{l}\text { Place of residence: } \\
\text { village } \\
\text { town up to } 5 \text { thousand } \\
\text { town from } 5 \text { to } 10 \text { thousand } \\
\text { town from } 10 \text { to } 50 \text { thousand } \\
\text { town from } 50 \text { to } 100 \text { thousand } \\
\text { city over } 100 \text { thousand }\end{array}$ & $\begin{array}{l}19(13.19) \\
1(0.7) \\
3(2.08) \\
17(11.08) \\
18(12.5) \\
85(59.02)\end{array}$ & $\begin{array}{l}6(6.66) \\
- \\
1(1.10) \\
7(7.8) \\
14(15.59) \\
62(68.9)\end{array}$ & $\begin{array}{l}13(24.07) \\
1(1.9) \\
2(3.8) \\
10(18.9) \\
4(7.5) \\
23(43.4)\end{array}$ & \\
\hline $\begin{array}{l}\text { Seniority [years]: } \\
X \pm S D \\
\text { min.-max. }\end{array}$ & & $\begin{array}{l}11.08 \pm 12.80 \\
1-40\end{array}$ & & \multirow[t]{2}{*}{$\begin{array}{l}r=0.765 \\
p=0.0001\end{array}$} \\
\hline $\begin{array}{l}\text { Seniority in the last workplace [years]: } \\
X \pm S D \\
\text { min.-max. }\end{array}$ & & $\begin{array}{l}6.36 \pm 8.78 \\
0.5-34\end{array}$ & & \\
\hline $\begin{array}{l}\text { Workplace: } \\
\text { primary care facility } \\
\text { other healthcare entities }\end{array}$ & & $\begin{array}{l}25(27.8) \\
65(72.2)\end{array}$ & & $\begin{array}{l}Z=-0.914 \\
p=0.361\end{array}$ \\
\hline \multirow{3}{*}{$\begin{array}{l}\text { Social activity: } \\
\text { scientific society } \\
\text { social organization } \\
\text { informal group }\end{array}$} & 28 (19.58) & $23(25,55)$ & $5(9,4)$ & $\begin{array}{l}\text { chi }^{2}=8,83 \\
p=0,003\end{array}$ \\
\hline & $7(4.9)$ & $7(7.8)$ & - & - \\
\hline & $14(9.8)$ & $11(12.22)$ & $3(5.7)$ & $\begin{array}{l}\text { chi }^{2}=4.852 \\
p=0.028\end{array}$ \\
\hline $\begin{array}{l}\text { Teaching activity: } \\
\text { teaching students } \\
\text { preparing and conducting training }\end{array}$ & & $\begin{array}{l}39(43.3) \\
16(17.8)\end{array}$ & & \\
\hline
\end{tabular}

Z - statistics of the Mann-Whitney U test: rho - Spearman's rank correlation; chi $^{2}$ - Pearson's test of independence; $p$ - significance level. 
with social competence, $Z$ statistics of the Mann-Whitney $U$, rho-Spearman's and Pearson's chi-squared tests were applied. For statistically significant results an odds ratio (OR) was determined, including a 95\% confidence interval. Test probability at a level of $p<0.05$ was assumed as statistically important for all tests. For statistical analysis SPSS v. 18 software was used.

\section{Results}

Physicians and medical students achieved average results of general social competence (sten score from 4 to 7 ) $62.23 \%(89)$, as well as in all three scales: $I-60.84 \%(87)$, $E S-62.63 \%$ (89) and $A-66.43 \%$ (95) (Tab. 2). $17.4 \%$ of the subjects from both groups revealed a low level of general social competence (sten score 1-3), while $23.07 \%$ (33) demonstrated low competence in situations requiring assertiveness. This group included $21.1 \%$ (19) of physicians, mainly women $(23.33 \%, 14) .20 .97 \%$ (30) of the subjects have high competence in intimate situations $(\mathrm{I})$, which is associated with communicative competence in interpersonal relationships.

A statistically important correlation between level of competence $I$ and ES and sex was demonstrated. Women achieved average and high results, while men - low and average. However, men have a higher level of competence $A$ than women (Tab. 3).

The results of general social competence acquired during social training dependent on environmental impacts

\begin{tabular}{|c|c|c|c|c|c|c|}
\hline \multirow{2}{*}{$\begin{array}{l}\text { Competence scales accord- } \\
\text { ing to SCQ }\end{array}$} & \multicolumn{3}{|c|}{ Sten scores } & \multicolumn{3}{|c|}{ Competence levels - stens ( $n, \%)$} \\
\hline & Me & $\min .-\max$. & $Q_{1}-Q_{3}$ & $\begin{array}{l}1-3 \\
\text { low }\end{array}$ & $\begin{array}{l}4-7 \\
\text { average }\end{array}$ & $\begin{array}{l}8-10 \\
\text { high }\end{array}$ \\
\hline I & 6.00 & $1-10$ & $4-7$ & $\begin{array}{l}26 \\
18.18\end{array}$ & $\begin{array}{l}87 \\
60.84\end{array}$ & $\begin{array}{l}30 \\
20.97\end{array}$ \\
\hline$E S$ & 5.00 & $1-10$ & $4-7$ & $\begin{array}{l}25 \\
17.48\end{array}$ & $\begin{array}{l}89, \\
62.23\end{array}$ & $\begin{array}{l}29, \\
20.28\end{array}$ \\
\hline$A$ & 5.00 & $1-10$ & $4-6$ & $\begin{array}{l}33, \\
23.07\end{array}$ & $\begin{array}{l}95 \\
66.43\end{array}$ & $\begin{array}{l}15 \\
10.49\end{array}$ \\
\hline General competence & 5.00 & $1-10$ & $4-7$ & $\begin{array}{l}28 \\
17.4\end{array}$ & $\begin{array}{l}89 \\
62.23\end{array}$ & $\begin{array}{l}26 \\
18.18\end{array}$ \\
\hline
\end{tabular}

Scales: competence conditioning effectiveness of behaviors in the following situations: $I$ - intimate; $E S$ - social exposure; $A$ - demanding assertiveness.

\begin{tabular}{|c|c|c|c|c|c|c|c|c|c|}
\hline \multirow[t]{3}{*}{ SCQ scales } & \multicolumn{3}{|l|}{ Scale I } & \multicolumn{3}{|c|}{ Scale ES } & \multicolumn{3}{|l|}{ Scale A } \\
\hline & \multirow[t]{2}{*}{ Total } & \multicolumn{2}{|l|}{ Sex } & \multirow[t]{2}{*}{ Total } & \multicolumn{2}{|l|}{ Sex } & \multirow[t]{2}{*}{ Total } & \multicolumn{2}{|l|}{ Sex } \\
\hline & & $M$ & $F$ & & $M$ & $F$ & & $M$ & $F$ \\
\hline$N$ & 143 & 42 & 101 & 143 & 42 & 101 & 143 & 42 & 101 \\
\hline$\%$ & 100.00 & 29.4 & 70.6 & 100.00 & 29.4 & 70.6 & 100.00 & 29.4 & 70.6 \\
\hline Median & 6.00 & 4.50 & 6.00 & 5.00 & 5.00 & 6.00 & 5.00 & 5.50 & 5.00 \\
\hline Min. & 1 & 1 & 1 & 1 & 1 & 1 & 1 & 1 & 1 \\
\hline Max. & 10 & 10 & 10 & 10 & 10 & 10 & 10 & 10 & 10 \\
\hline Q1 & 4.00 & 2.00 & 5.00 & 4.00 & 2.75 & 4.50 & 4.00 & 4.00 & 3.5 \\
\hline Q3 & 7.00 & 5.25 & 8.00 & 7.00 & 6.00 & 7.00 & 6.00 & 7.00 & 6.00 \\
\hline$Z$ & & \multicolumn{2}{|c|}{-4.281} & & \multicolumn{2}{|c|}{-2.915} & & \multicolumn{2}{|c|}{-1.959} \\
\hline$p$ & & \multicolumn{2}{|c|}{0.0001} & & \multicolumn{2}{|c|}{0.004} & & \multicolumn{2}{|c|}{0.05} \\
\hline
\end{tabular}

$Z-Z$ statistics of Mann-Whitney $U$ test.

\begin{tabular}{|c|c|c|c|c|c|c|c|}
\hline \multirow[t]{2}{*}{ SCQ } & \multirow[t]{2}{*}{ Total } & \multicolumn{2}{|l|}{ Sex } & \multicolumn{2}{|c|}{ Professional status } & \multicolumn{2}{|c|}{ Physicians' workplace $(n=90)$} \\
\hline & & Man & Woman & Student & Physician & Primary care facilities & Other healthcare entities \\
\hline$n$ & 143 & 42 & 101 & 53 & 90 & 25 & 65 \\
\hline$\%$ & 100.00 & 29.4 & 70.6 & 37.1 & 62.9 & 27.8 & 72.2 \\
\hline Median & 5.00 & 5.00 & 6.00 & 5.00 & 6.00 & 5.00 & 6.00 \\
\hline Min.--max. & $1-10$ & $1-10$ & $1-10$ & $1-10$ & $1-10$ & $2-9$ & $1-10$ \\
\hline Q1 & 4.00 & 4.00 & 3.00 & 4.00 & 4.00 & 4.00 & 4.00 \\
\hline Q3 & 7.00 & 7.00 & 7.00 & 6.50 & 7.00 & 8.00 & 7.00 \\
\hline$Z$ & & \multicolumn{2}{|c|}{-1.377} & \multicolumn{2}{|l|}{-1.375} & \multicolumn{2}{|l|}{-0.036} \\
\hline$p$ & & \multicolumn{2}{|c|}{0.168} & \multicolumn{2}{|l|}{0.169} & \multicolumn{2}{|l|}{0.971} \\
\hline
\end{tabular}

$Z-Z$ statistics of Mann-Whitney $U$ test. 
were compared. The physicians employed in primary care facilities achieved average and high results (Q1-Q3 $=4-8)$, while those employed in other healthcare entities achieved average levels - Q1-Q3 = 4-7 (Tab. 4).

The physicians employed in primary care facilities in situations requiring assertiveness $A$ obtained low and average results $(\mathrm{Q} 1-\mathrm{Q} 3=3.00-6.00)$, while the physicians employed in other healthcare entities obtained average results (Q1-Q3 = 4.00-6.00).

Involvement in the education of students and co-workers was declared by $44 \%$ (11) of physicians employed in primary care facilities and $84.61 \%$ (55) of physicians of other healthcare entities. Physicians involved in teaching students have a significantly higher level of $E S$ competence $(Z=-2.08$; $p=0.04$ ) than physicians who do not teach students. Physicians preparing and conducting training for co-workers also have a significantly higher level of $E S$ competence $(Z=-2.47$; $p=0.01)$.

\section{Odds ratio}

- $\quad$ The odds ratio for the physicians to achieve at least 5 sten score (average to high level) in the total result of social competence increases by $8.5 \%$ with every successive year of seniority (Tab. 5).

- Membership in scientific societies increases fivefold the odds of a high level of general social competence in the $E S$ scale and fourfold in the $A$ scale.

- Physicians educating medical students were 0.07 times less likely to achieve an average and high ( 5 sten score) results in the $A$ scale.

- Male physicians are 0.32 times less likely to achieve an average level ( 4 sten score) of competence in the I scale and 0.28 times in the $E S$ scale.

- $\quad$ Third cycle degree studies increase 7.48 times the odds of achieving a high level of $A$ competence, and residing in a city of up to 100 thousand inhabitants increases threefold the odds of obtaining at least 5 sten score.

- With increasing seniority in the last workplace, the odds of obtaining a high level of $A$ competence decrease 0.93 times.

- Male students are 0.21 times less likely to obtain at least 5 sten score of $I$ competence than women $-\mathrm{OR}=$ $0.205,95 \% \mathrm{Cl}(0.04-0.95) ; p=0.04$.

\section{Discussion}

The social competence of healthcare professionals, including communication and interpersonal competence are important factors which affect the quality of care and satisfaction of patients with health services $[12,14,15]$. In the study group average levels of social competence dominate, which allow physicians and medical students to engage in relatively effective action in social situations. However, a large group of physicians $(23.07 \%)$, mainly women $(23.33 \%)$, are characterized by a low level of competence in situations requiring assertiveness. Assertiveness is a complex set of task-related, interpersonal and expressive competencies which enable the effective fitting of one's own and others' social needs $[2,16]$; therefore, people with low assertive competence should be provided with educational programs allowing its acquisition [17]. Wołoszczak-Szubzda and Jarosz found that in study programs little time is dedicated to the development of skills of professional communication with different social groups [18]. Henry et al. are of the same opinion, and indicate that communication with the patient is the most common and important activity in medical practice, but in medical education not enough importance is attached to the development of this competence [19]. Jankowska and Pasierski believe that the introduction of social training in the field of communicative competence to the curriculum in medical schools and to medical practice will improve relationships between patients and physicians, and will allow an increase in the effectiveness of medical care [12]. The authors' own research demonstrates that higher competencies of physicians conditioning the effectiveness of behaviors in situations of social exposure (ES), which means being the object of attention and potential assessment on the part of many people, are associated with social training, which includes teaching students, as well as preparing and conducting training and professional work. Other results were obtained by the team of Mehdizadeh in a retrospective cohort study, determining competence in the field of physical examination, cardiopulmonary resuscitation (CPR), and communicative competence in groups of 95 general practitioners (graduated in the years 1961-2004) and 376 physicians graduated in 2005 or later. It was found that medical knowledge, CPR competence and communicative competence increased with seniority in general

\begin{tabular}{|c|c|c|c|c|c|c|}
\hline Variables & $\beta$ & Standard error & Wald & $p$ & OR & $95 \% \mathrm{CI}$ for $\mathrm{OR}$ \\
\hline \multicolumn{7}{|l|}{ SCQ total result } \\
\hline Membership in a scientific society & 1.71 & 0.69 & 5.99 & 0.01 & 5.52 & $1.41-21.64$ \\
\hline Seniority in years & 0.08 & 0.04 & 4.37 & 0.04 & 1.10 & $1.01-1.17$ \\
\hline \multicolumn{7}{|l|}{ Competence I } \\
\hline Sex & -1.14 & 0.49 & 5.54 & 0.02 & 0.32 & $0.12-0.825$ \\
\hline \multicolumn{7}{|l|}{ Competence ES } \\
\hline Sex & -1.26 & 0.56 & 5.00 & 0.02 & 0.28 & $0.09-0.86$ \\
\hline Membership in a scientific society & 1.41 & 0.69 & 4.16 & 0.04 & 4.10 & $1.06-5.91$ \\
\hline Place of residence & 1.39 & 0.63 & 4.91 & 0.02 & 4.02 & $1.17-3.79$ \\
\hline \multicolumn{7}{|l|}{ Competence $A$} \\
\hline Teaching students & -2.60 & 0.92 & 7.94 & 0.01 & 0.07 & $0.01-0.453$ \\
\hline Membership in a scientific society & 1.54 & 0.73 & 4.50 & 0.03 & 4.67 & $1.12-19.45$ \\
\hline Place of residence & 1.11 & 0.61 & 3.33 & 0.06 & 3.04 & $0.92-10.02$ \\
\hline Currently studies & 2.01 & 0.95 & 4.46 & 0.03 & 7.48 & $1.16-48.38$ \\
\hline Seniority in the last workplace & -0.07 & 0.04 & 3.22 & 0.07 & 0.93 & $0.85-1.01$ \\
\hline
\end{tabular}


practitioners [20]. On the other hand, the physicians who graduated after 2005 obtained lower scores in the test of knowledge, but higher scores in the overall skills assessment using the OSCE - Objective Structured Clinical Examination method and in communication skills assessment [20]. Based on the results of existing studies related to the social competencies of physicians, Kavic identified 7 general key competencies considered necessary: patient care, medical knowledge, professionalism, practice based on procedures, learning based on experience, interpersonal communication and professional skills [21].

\section{Limitations of the study}

The presented results should be considered preliminary and requiring further research, as they have indicative value for entities and individuals managing the education of medi- cal staff, which allows for undertaking steps to master social competence determining professional and social success.

\section{Conclusions}

Low levels of competence can be expected from physicians with less seniority, not belonging to scientific societies, not involved in students' education, working in only one place, and not participating in third cycle degree studies. This group should be provided with social competence training.

Exploration of the social competence of physicians and medical students is necessary to determine the needs for specialized training to acquire social competence, and to develop programs for the acquisition of the social competence of managing complex professional and social situations [11].

Source of funding: This work done within the framework of the research project Stimulation Fund for Science No. FSN-366-11 / 14, funded by the Pomeranian Medical University in the years 2015-2017.

Conflict of interest: The authors declare no conflict of interests.

\section{References}

1. White RW. Motivation reconsidered: the concept of competence. Psychol Rev 1959; 66(5): 297-333.

2. Martowska K. Temperamental determinants of social competencies. PPB 2014; 45(2): 128-133.

3. Matczak A. Kwestionariusz kompetencji społecznych. Podręcznik. 2nd ed. Warszawa: Pracownia Testów Psychologicznych PTP; 2012.

4. Smółka P, Szulawski M. Personality traits and motivational traits as predictors of social competence. Implication for occupational selection process. EEiM 2011; 4(22): 111-126.

5. Matczak A. Preferencje zawodowe młodzieży a kompetencje społeczne. Psychol Wychow 1998; 41: $28-36$.

6. Austin EJ, Saklofske DH, Egan V. Personality, well-being and health correlates of trait emotional intelligence. Pers Indiv Differ 2005; 38: 547-558.

7. Engelberg E, Sjöberg L. Emotional intelligence, affect intensity, and social adjustment. Pers Indiv Differ 2004; 37: 533-542.

8. Palmer B, Donaldson C, Stough C. Emotional intelligence and life satisfaction. Pers Indiv Differ 2002; 33: 1091-1100.

9. Ahn D. What is the social competency for doctors? J Korean Med Assoc 2014; 57(2): 96-103.

10. Epstein RM, Hundert EM. Defining and assessing professional competence. JAMA 2002; 287(2): 226-235.

11. Tychmanowicz A, Kuśpit M. Social competences of health service workers. Pilot study. Prog Health Sci 2012; 2(1): 107-112.

12. Jankowska K, Pasierski T. Medical communication: a core medical competence. Pol Arch Med Wew 2014; 124(7-8): 350-351.

13. Bryl N, Horst-Sikorska W, Ignaszak-Szczepaniak M, et al. Influence of social competence of physicians on patient compliance with osteoporosis medications - a study on Polish postmenopausal women. Ginekol Pol 2012; 83(7): 511-516.

14. Derkacz M, Chmiel-Perzyńska I, Kowal A, et al. Rozumienie zaleceń lekarzy - niedoceniany problem w codziennej praktyce lekarza rodzinnego. Fam Med Prim Care Rev 2010; 12(3): 618-621.

15. Polskiego Pacjenta Portret Własny. Raport o przestrzeganiu zaleceń terapeutycznych przez polskich pacjentów. Warszawa: Fundacja Wspieranie Polskiej Farmacji i Medycyny; 2010: 32.

16. Alberto R, Emmons M. Asertywność. Gdańsk: Wydawnictwo PTP; 2002: 62.

17. St George I, Kaigas T, McAvoy P. Assessing the Competence of Practicing Physicians in New Zealand, Canada, and the United Kingdom: Progress and Problems. Fam Med 2004; 36(3) 172-177.

18. Wołoszczak-Szubzda A, Jarosz MJ. Selected aspects of a professional doctor-patient communication - education and practice. Ann Agric Environ Med 2013; 20(2): 373-379.

19. Henry SG, Holmboe ES, Frankel RM. Evidence-based competencies for improving communication skills in graduate medical education: A review with suggestions for implementation. Med Teach 2013; 35(5): 395-403, doi: 10,3109/0142159X.2013.769677.

20. Mehdizadeh L, Sturrock A, Dacre J. Are the General Medical Council's Tests of Competence fair to long standing doctors? A retrospective cohort study. BMC Medical Education 2015; doi: 10.1186/s12909-015-0362-x.

21. Kavic MS. Competency and the six core competencies. JSLS 2002; 6(2): 95-97.

Address for correspondence:

Bożena Mroczek, PhD, Assoc. Prof.

Zakład Nauk Humanistycznych w Medycynie PUM

ul. Gen. Chłapowskiego 11

71-204 Szczecin

Polska

Tel.: +48 91 44-14-751

E-mail: bozena.mroczek@pum.edu.pl,b_mroczek@data.pl. 